I University of Virginia, Charlottesville, VA, United States of America

iar2c@virginia.edu

https://orcid.org/0000-0002-6318-763X

Isaac Ariail Reed'

\title{
MAX WEBER, HANNAH ARENDT, AND THE QUESTION OF CIVIL POWER
}

In The Civil Sphere, Jeffrey C. Alexander sets out a counter-program to the "tradition of Thrasymachus." By this phrase he refers to the debunking, realist tradition of thinking about power, a tradition of thought that meets claims to authority with a knowing smirk, insisting that "'Just' or 'right' means nothing but what is in the interest of the strongest party" (Alexander, 2006: 40). The intellectual efforts of both The Civil Sphere and the series of studies that have come after it are directed towards a renovation of the sociological analysis of politics so as to unseat the tendency to understand politics only in terms of variation in access to and use of means regardless of ends (which, in the realist tradition, are set elsewhere, off stage, if they are set at all). The outlines of Alexander's counter-argument to Thrasymachus (and to the modern avatars of the realist tradition, e.g. Karl Marx, Theda Skocpol) are well-known and much debated: Alexander argues for the (historically and geographically variable) presence of a sphere of horizontal solidarity and mutual obligation, which can inflect the push and pull of social life emphasized by the phrase "A has power over B when..." (Lukes, 2004).

But debates on the multifaceted argument of The Civil Sphere focus too little, in my view, on a very clear and plain fact. The argument of the text travels not only through well-known theoretical terms such as 'solidarity,' 'discourse,' 'incorporation,' and, of course, 'justice' and 'democracy,' but also through the phrase - which I view as fundamental to the entire book - 'civil 
power.' It is this phrase which locates Alexander's effort as simultaneously Durkheimian and Weberian, because it captures Alexander's inheritance of Weber's concern with power, alongside his inheritance of Weber's theorization of complex societies in terms of the differentiation of value-spheres. Furthermore, as I will argue here, the concept of civil power locates the effort of The Civil Sphere in an intellectual space that takes its coordinates not (or not only) from a conversation about culture and power found in Jürgen Habermas, Pierre Bourdieu and Michel Foucault, but also from an earlier generation of thinkers whose responses to Weber were vital for setting the parameters of the EuroAmerican critical social theory that spanned the Atlantic in the early and midtwentieth century. It is this latter conversation that is coming into view today as essential, and it is as a contribution to this latter conversation that I wish to interpret Alexander's work in The Civil Sphere and beyond. If Habermas, Bourdieu and Foucault can be characterized as engaged in an argument both of and about the trentes glorieuses and their aftermath, one can detect in The Civil sphere a reaching back to go forwards, one which is particularly apposite to our present moment.

\section{WHAT IS CIVIL POWER?}

The concept of civil power does three kinds of work in The Civil Sphere. First, it constitutes an intervention into realist-structuralist theories of state-society relations. In (relatively) democratic societies, Alexander argues, civil power, via institutions like voting, emerges as a 'gate' that swings open (or not) between the space of social power (in which hierarchy emerges from wealth and status) and the space of political power (in which capacity-including capacity for coercion-accrues to those who occupy positions inside the state) (Alexander, 2006: I Io). Only by going through the trials and tribulations of civil power, the drama and counter-drama of campaigns, and the appeal to represent 'the people,' can a member of the social elite come to command the state apparatus. The argument, then, is that in the regulative institutions of voting, party, office, and law, the civil sphere as a space of interpretation intervenes as a 'third player' to the realist games of (socio-economic and political) power. (Indeed, the theoretical similarity between the role of civil power as mediator and the dynamics Simmel attributes to the triad is remarkable and worthy of further investigation) (Simmel, I950: I35ff). Civil interpretations are mediative in two senses, then: they mediate between different sources of power, and they provide the signs and meanings in which regimes must be felicitously presented, if they are to effectively wield power.

And so, second, with the concept of 'civil power,' Alexander opens up for investigation the dependence of power - civil power, and, in a mediated way, social and political power - on interpretation. For example, it is by examining interpretation in terms of the "idealizing, if bifurcated, vision of the motives, relations, and institutions that allow civil society" that Alexander can reveal 
the "cultural dimension of democratic law" (for example, the way in which the actions of juries are interpreted with reference to a normative standard of civil motives and relations) (Alexander, 2006: I59). A trial is a moral performance, and in a democratic society, such a performance must translate and interpret, for the concrete matter at hand, the background myth of a free and fair ('civil') society. Note that here Alexander turns to what is perhaps the paradigmatic case of the coercive power of the state - the binding outcome of a criminal trial. Indeed, those exclusions enforced by law that are manifestly undemocratic are analyzed in terms of the way in which "in a stratified and segmented society [the lawmaker's] capacity or interpretive understanding is often sharply curtailed," precisely in so far as the civil binaries are fused to other, status and wealth-based distinctions that bar dominated members of society from being able to be interpreted as moral, upstanding, autonomous citizens deserving of full recognition.

This re-analysis of law points to the third kind of work 'civil power' does in the text. The theory of the civil sphere is - particularly in Chapters 6 and 7 - mobilized in the particularly difficult 'cases' of parties and law - those houses of coercion and raw power that would initially appear to be the opposite of 'communication.' This appears to be a somewhat underappreciated part of the book, since to argue that the law is a space of civil interpretation, given its intricate involvement with the machinery of state and the most egregious exclusions of the modern era, is to put the theory to a rigorous test. After all, Alexander notes in the chapter on law, even Kelsen, liberal defender of democracy as Germany descended into darkness, described law as a "norm which stipulates a sanction." Alexander notes in response: "the realist position, despite its democratic origins in late-nineteenth-century social reform, is perfectly compatible with this anti-idealist spirit" (Alexander, 2006: I58).

Having articulated what I think civil power is and does, qua concept, for Alexander's text, I wish now to meditate upon the space of argument to which this text can be considered a contribution.

\section{NOTES ON THE SPIELRAUM BETWEEN WEBER AND ARENDT}

Surely the most influential sociological inheritor of the tradition of Thrasymachus is Max Weber, whose realism melded with his appreciation of the complexities of culture to fashion a sociology that, at certain moments, approached the multidimensional (Alexander, I983). Nonetheless, as Michael Smith (1987) has made clear, and despite the dependence of the cultural turn in the sociology of the state on Weber's work, we can see in Weber a repeated and clear preference for conceptualizing the state in terms of its coercive power over the population, variably legitimated. If power is "the chance of a man or a number of men to realize their own will in a communal action even against the resistance of others who are participating in the action;" if politics and political parties live in a 
"house of power" that is itself defined in relation to the modern state; and if the modern state can only be defined sociologically "in terms of the specific means peculiar to it...namely, the use of physical force," then that which is of the state is of violence. In the end, for Weber (I946: 78; I80), 'politics' is the laborious struggle over access to the use of that violence and coercion which can be legitimated.

The theoretical difficulties that have grown out of this line of thought are famous for their capacity to generate creativity and insight, for what Weberian sociology then asks us to think about is how the struggles over the command of the state apparatus can occur in various ways, including highly symbolic gestures and speeches, and actions (including voting) that are manifestly non-violent. This means that one way to define twentieth-century EuroAmerican social theory itself is as a conceptual struggle to grasp the relation of citizen and state, given the twin growth, in the Western world, of immense capacities for violence put at the discretion of those who occupy certain positions in state organizations and the legitimation mechanism that Weber sometimes called the will of the ruled and we often call 'democracy.' Indeed, from Weber's articulation of the dilemmas of modern politics came two remarkably different 'answers' to Weberian questions - the legal theories of Hans Kelsen (already mentioned), and those of Carl Schmitt. Alexander's work makes quite clear how Schmitt's normative theory of state power in fact describes a society in which there is no autonomous civil sphere, and thus the possibility of civil power has evaporated or collapsed (Schmitt, 2008).

But, from the space defined by Schmitt and Kelsen came, also, the social and political theory of Hannah Arendt, whose writings about power, authority and violence form an intriguing counterpoint to Weberian realist sociology and political science. Arendt's approach to power - the possibility of people 'acting together' and, in particular, engaging in public with each other in such a way that those involved accept an uncertainty of outcomes - seems, to many sociologists, an impossibly normative, even utopian, theory of power. This is already a misreading, particularly if we set Arendt's admittedly idiosyncratic definition of power in the context of her political philosophy as a whole. In many ways, Arendt's political philosophy is more comprehensively aware of the consistent and tragic flaws of human motivation and engagement (Markell, 2003), and the dramaturgical aspects of social life traced so well by Erving Goffman, ${ }^{\mathrm{I}}$ than are the rationalist philosophies of right against which her work can be set. In other words, Arendt's theory is surely a political philosophy, but her account of power and action provides a superior account of publicity, action and reaction to social movements, and thus modern democratic struggles, than does Habermas's theory of the public sphere as a deliberative space. ${ }^{2}$

But what is particularly important to observe is that Arendt's definition of the relationship of politics to violence is the precise inverse of Weber's, and this is what lies at the root of (I) her redefinition of power as people acting together 
in concert, (2) her insistence that to grasp at such power, people have to appear before each other in a space in which the relationship between persons is not a relation of despotic rule, and, finally, (3) her well-known argument that when violence appears, there power stops, declines, or begins to leave the scene.

One may propose that the insight that grounds this (to a sociologist, somewhat enigmatic) series of Arendtian ideas is as follows: Violence is the paradigmatic instance of instrumentality in human life. Is this true? It is, perhaps, a question of philosophical anthropology that cannot be resolved empirically. But Wolfgang Popitz (20I7) constructed a significant sociological architecture around the idea that asymmetries in strength are the model for other, more sociologically familiar asymmetries in wealth and organizational position. Arendt argued, in line with this, that violence is the enhancement of strength via the use of technology and materiel. And, unlike the more mediated and system-dependent forms of instrumental domination, violence entails a direct attack on the target's ability to be a person. As such, violence, when it appears, is the direct inverse of speech that presumes, in an implicit way, that speaker and hearer can be understood as equal in their difference. As Arendt writes:

Human plurality, the basic condition of both action and speech, has the twofold character of equality and distinction. If men were not equal, they could neither understand each other and those who came before them nor plan for the future and foresee the needs of those who will come after them. If men were not distinct, each human being distinguished from any other who is, was, or will ever be, they would need neither speech nor action to make themselves understood. Signs and sounds to communicate identical needs and wants would be enough (Arendt, I998: I75-I76).

The result of this quite hermeneutic invocation of the layers of meaning that necessarily attend and are a source of plurality, is that politics, as the union of speech and deed that constitutes the distinctly human phenomenon of action (praxis), is simply the use of persuasion to build alliances (through deeds as well as words; through character as well thought), and in this way to carry the day in the open field of agonistic public contention. This, quite precisely, is what evaporates the moment when violence arrives. It is worth noting various interesting implications of this view, some of which match quite well the intellectual instincts of cultural sociology. First, 'politics' can take place wherever such processes of persuasion emerge; there can be 'politics' inside a work organization, a church, a community center. Politics that engages the state, furthermore, can be interstitial and multidirectional; it can treat the state as a necessary part of its symbolic and organizational environment without seeking the 'rule of' the state, or even to change laws (Arendt's own work with Zionist organizations to help Jewish people leave Europe was politics in this sense). Finally, one can trace to this notion of politics Arendt's core insight about the disasters of the twentieth century and her remarkable difference from Habermas. 
Unlike Habermas's 'unfinished project' of modernity, Arendt refused to ground the possibility of a good society in the rule of law and the protection of individuals from state and society as secured in the law (Weimann, 2018); she distrusted the engineering imagery that attended much Enlightenment political philosophy. Instead, Arendt retained a suspicion that states and other bureaucracies could never be expected to ensure their own accountability to the population, no matter how 'rationally' conceived. She insisted that positive law, administrative rationality, and their cognates could not contain, 'in themselves' the thick normative meanings that could, in fact, sustain a democratic society. Rather, it was only in the ability of citizens to appear before each other, and in so doing, appeal to a cultural milieu in which a tradition of equality and democracy carried tremendous weight, that one could hope to keep the terrifying capacities of modern state organizations 'under control.'

\section{THE INFLECTION OF HIERARCHY BY CIVIL INTERPRETATION AND THE QUESTION OF 'THE SOCIAL'}

There is, then, a great forum (or agora) for theoretical and empirical interpretation between Weber and Arendt, and it is in this space that Alexander's interpretations of law, party and office come into their own. Alexander writes, for example:

Without solidarity, civil power cannot be produced, and without its moral pressure the officeholder will not feel an obligation to civil society in turn. Without such a sense of civil obligation, indeed, officials will not be attentive even to social power. [...] When solidarity is more expansive, and the pressures of 'society' become more explicit and powerful, office becomes an outpost of civil society directly inside the state. [...] When there is a developed civil sphere, communicative institutions, can, at any moment, leverage putative office regulation into 'affairs' and 'scandals' (Alexander, 2006: I34-I35).

How to read this argument? It strikes me that it is not an argument about a Durkheimian 'society' acting itself out behind our backs, but rather an argument about the consequential ways in which acting together and not acting together constitute the variable likelihood that power/violence in the Weberian sense can be reined in (or, in a sense, reigned out, by the making of democratic sovereignty). Alexander's argument is, then, that (I) certain hierarchical relations, in certain times and spaces, are subject to regulation via norms of reciprocity, (2) that they are so subject because the hierarchies are themselves embedded in a series of narratives and codes that make action comprehensible as worthy and unworthy of moral esteem, and finally (3) that the subjection of persons to exploitation, violence, and other forms of 'harm' is itself, in part, a result of the interpretation of such persons as unworthy of fair treatment due to their (interpreted) lack of 'civil qualities.' I do not think that these three 
arguments have to be taken as a package, and their empirical veracity should differ tremendously across time and space: they set up parameters for empirical study.

However, if we read Alexander's argument in this (perhaps heterodox) way, it also opens onto a theoretical problem of significance, one which I think is bequeathed to us by Alexander's text but not resolved. This problem concerns the rather sharp difference between Alexander's synthesis of the Durkheimian and Weberian traditions for thinking about politics and culture in society, and Arendt's well-known melancholy about the rise of the social, which framed her own discomfort with, and dissent from, the sociological tradition. What are we to make of this difference?

One way to see the problematique created is in the following way. The Civil Sphere inherits the tradition of thinking about solidarity in sociology, but jettisons both the evolutionary narrative about solidarity's expansion in modernity, and the hermeneutic deafness of a sociology of solidarity that studies emotions and social ties without differentiating them in terms of the meanings through which they are articulated. In discarding the latter two, Alexander moves closer to Arendt's position in political philosophy, but retains a set of empirical arguments about the trajectories and counter-trajectories of the meaning of recognition. These trajectories flow through society via the very institutions and organizations that Arendt often included in her accounts of the "rise of the social," wherein she took part in the discourse of suspicion (Ricoeur, I970). Indeed, one can see a certain irony in this intellectual situation. Arendt's distaste for sociological functionalism is, in part, hermeneutic - she cannot abide its removal of the study of meaning-in-the-world by theoretical fiat. But, this impatience with the sociology of the postwar era also led her to underestimate certain circuits of the social as circuits of civil society.

Interestingly, however, Arendt's account of the rise of the social went to great lengths to insist that the social qua 'tyranny of opinion' made its initial appearance in Western modernity in the hierarchical world of the ancien régime, and especially its salons and their accompanying notion of 'good society.' ${ }^{3}$ Thus, for Arendt, even if the tyranny of opinion continued to effloresce in the (nominally) egalitarian societies whose politics owed a great deal to the Atlantic revolutions, the rise of the social did not necessarily 'jump together' with the emergence of modern claims to equality. So, her skepticism about the social is not, at its core, a reading of liberal democracies as mass societies; rather her concern is with the erasure of difference and human plurality through a tyranny of opinion derived from social power characteristic of the long arc of the modern era. One might, then, imagine civil power as a counterforce to this. Could we tell a story about the rise of the social and its complex, sometimes deleterious effects - a story that would, itself, contextualize the founding of sociology as a response to the social question - and yet also 
account for how, via civil power, certain possibilities of recognition can resist the homogenizing effects of mass sameness? And what politics could grasp at popular sovereignty while specifically excluding the temptations of a (fantasized) homogeneous demos? These are, perhaps, the theoretical challenges revealed by the concept of civil power.

Received on 3/10/2018 | Approved on 6/2/2019

Isaac Ariail Reed is Associate Professor of Sociology at the University of Virginia. He is the author of Interpretation and social knowledge: On the use of theory in the human sciences (20I I), and the co-editor, with Claudio Benzecry and Monika Krause, of Social theory now (2017). 


\section{NOTES}

I Especially relevant here are the extended discussions of action, appearance and performance in The Human Condition (Chicago: University of Chicago Press, I998).

2 As this is a special issue including pieces from many of Alexander's PhD students, it is perhaps worth noting that this point about Arendt was part of Alexander's teaching of Habermas. For an interpretation of Arendt's theory of action as central for sociology, see "The Human Condition and the theory of Action" in The Anthem Companion to Hannah Arendt, edited by Peter Baehr and Philip Walsh (Anthem Press, 2017, p. 50-74).

3 Arendt attributes great importance to the salons in The Human Condition, and Seyla Benhabib's famous reading of the "melancholy modernism" of Arendt begins with a study of Arendt's work on a Jewish salonnière (The Reluctant Modernism of Hannah Arendt [New York: Rowman \& Littlefield, I996]). This interest is shared by Joan Landes, whose text Women and the Public Sphere in the Age of the French Revolution (Ithaca: Cornell University Press, I988) was required reading when I studied with Alexander, and whose retelling of the modern story effectively, in my view, bursts the Habermasian frame from which it begins.

\section{BIBLIOGRAPHY}

Alexander, Jeffrey C. (2006). The civil sphere. New York: Oxford University Press.

Alexander, Jeffrey C. (1983). Theoretical logic in sociology. Volume 3: The classical attempt at synthesis: Max Weber. Berkeley, CA: University of California Press.

Arendt, Hannah. (1998). The human condition. Chicago: University of Chicago Press.

Lukes, Steven. (2004). Power: a radical view. Second Edition. London: Palgrave/MacMillan.

Markell, Patchen. (2003). Bound by recognition. Princeton, NJ: Princeton University Press.

Popitz, Wolfgang. (2017). Phenomena of power: authority, domination, and violence. New York: Columbia University Press. 
Ricoeur, Paul. (1970). Freud and Philosophy: an essay on interpretation. New Haven: Yale University Press.

Schmitt, Carl. (2008). The Leviathan in the State Theory of Thomas Hobbes: meaning and failure of a political symbol. Chicago: University of Chicago Press.

Simmel, Georg. (I950). The sociology of Georg Simmel. New York: The Free Press.

Smith, Michael J. (1987). Realist thought from Weber to Kissinger. Baton Rouge, LA: Louisiana State University Press. Weber, Max. (I946). Class, status, party; Politics as a vocation. In: Gerth, H.H. \& Wright Mills, C. (eds.). From Max Weber: essays in sociology. New York: Oxford University Press.

Weinman, Michael. (2018). Arendt and the legitimate expectation of hospitality and membership today. Moral Philosophy and Politics, 5/I, p. I27-I 49. 
Palavras-chave

Jeffrey C. Alexander;

poder;

sociedade civil;

democracia; sociologia política;

Keywords

Jeffrey C. Alexander;

power;

civil society;

democracy;

political sociology.

\section{MAX WEBER, HANNAH ARENDT E O PODER CIVIL}

\section{Resumo}

Este artigo investiga o conceito de "poder civil" no livro The Civil Sphere, de Jeffrey Alexander. Com isso, torna-se possível interpretar a obra situando-a entre as diferentes teorias e definições de poder presentes nos trabalhos de Max Weber e de Hannah Arendt. Lido assim, The Civil Sphere não se torna apenas um argumento durkheimiano sobre a solidariedade, mas também um argumento sobre os modos mais consequentes pelos quais agir em conjunto ou não agir em conjunto constituem um espaço de variação no grau em que o poder e a violência podem ser controlados, uma vez que eles são dominados na construção da soberania democrática.

\section{MAX WEBER, HANNAH ARENDT, AND THE QUESTION OF CIVIL POWER}

\section{Abstract}

This article traces the concept of 'civil power' in Jeffrey Alexander's book The Civil Sphere. Doing so leads to an interpretation of the work as operating in the space between the different theories and definitions of power in the work of Max Weber and Hannah Arendt. Read in this way, The Civil Sphere becomes not only a Durkheimian argument about solidarity, but also an argument about the consequential ways in which acting together and not acting together constitute a space of variation in the degree to which power and violence can reined in, in so far as they are reigned out in the making of democratic sovereignty. 